\title{
Traditional Vs. Contemporary Managerial/Cost Accounting Techniques Differences Between Opinions Of Educators And Practitioners
}

M. A. Ekbatani, Alameh University, Iran

M. A. Sangeladji, (Email: msangeladji@csun.edu), California State University, Northridge

\section{INTRODUCTION}

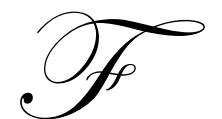

rom the mid 1980s, the start of new movements in the field of managerial/cost accounting, a gap has emerged between the opinions of academia and practitioners regarding the degree of usefulness of managerial/cost accounting techniques. It is believed that practitioners generally prefer managerial/cost accounting techniques which are simple, practical and economically applicable. On the other hand, many authors and academia believe that the traditional managerial/cost accounting techniques are obsolete and not effective for managerial decision-making purposes. As stated by one author, most of the traditional management/cost accounting information are usually too late, too aggregated, and too distorted to be relevant for decision-making purposes. ${ }^{\text {i }}$

Despite the considerable criticisms to the traditional techniques and increasing interest in developing new managerial/cost accounting models in recent years, the traditional management/cost accounting techniques are still widely used by many organizations. ${ }^{\text {ii }}$

Based on the above and many other studies, some disagreements appear to exist between the perception of academia and practitioner regarding the degree of usefulness of some traditional and contemporary (emergent) managerial/cost accounting techniques and practices. The objectives of this research were to determine (a) whether a real gap existed between the perceptions of academia and practitioners regarding the usefulness of traditional and contemporary managerial/cost accounting techniques and practices and (b) if such a real gap existed, should the practitioner follow academia or should academia modify their theoretical thinking according to practitioners' practical experiences. In addition, it was planned in this research to determine the degree of usefulness of different managerial/cost accounting techniques and practices, as well as the type of skills and characteristics demanded from our graduates, from the view points of academia and practitioners. The outcomes of this study were expected to provide useful and empirical information to the authorities in the higher education for the development of more effective curriculum in the field of managerial/cost accounting.

\section{REVIEW OF LITERATURES}

The accounting education has received significant criticisms in the past two decades. The oldest and most important criticism came from the study conducted by Bedford in 1986. According to this study "There is little doubt that the current of professional accounting education, which has remained substantially the same over the past 60 years, is generally inadequate for future accounting professionals. A growing gap exists between what accountants do and what accounting educators teach*** Accountants who remain narrowly educated will find it more difficult to compete in an expanding profession*** The committee's analysis of accounting practice had indicated that accounting education as it is currently approached requires major adjustments between now and the year 2000., 
Furthermore, the American Institute of certified Public Accountants (AICPA) and the American Accounting Associations (AAA) have also noted some problems with accounting education. For instance, the AICPA, after discussing the problems in the CPA version project 1998, has recommended some modifications in accounting education in order to meet the future needs of CPAs. The AAA committee, likewise, has recognized the problems and requested more involvement by educational institutions and universities in resolving them. According to the AAA committee, "A much broader role for accounting education than that being filled by most universities today" is needed to overcome the problems. ${ }^{\text {iv }}$

In regard to managerial and cost accounting, as noted by Johnson and Kaplan, 1987, most of the traditional techniques and practices used in managerial/cost accounting were old and some were rather obsolete. According to these authors,

By 1925 virtually all management accounting used today had been developed.... cost account for labor, martial and overhead, budget for cash, income and capital, flexible budget, sales forecasts, standard costs, variance analysis, transfer price and divisional performance measures (p12). ${ }^{v}$

As a result of the above observations and comments, a new movement has started in mid 1980 in the field of accounting, especially in the managerial and cost accounting. The movement started by Johnson and Kaplan in 1987, indeed, can be marked as the beginning of modern managerial/cost accounting. With the seeds provided by these authors, other authorities and scholars cultivated the modern managerial/cost accounting. As a result, they have developed the contemporary concepts, models, and techniques that are used today in the cost and managerial accounting. Table 1 presents a trend analysis by Ittner C.D \& Larcker D.F, 2001 about the development of managerial/cost accounting practices and techniques. ${ }^{\mathbf{v}}$

Table 2 demonstrates some of the modern and emergent techniques and practices in managerial/cost accounting with their contributors and time reference. Table 3 classifies most of the managerial/cost accounting techniques and practices into traditional and emergent (modern and contemporary) ones.

A question which has been raised by some authorities regarding the above classification in Table 3 is whether these two groups of techniques and practices are substitutes for or complimentary of each others. Chanhall \& Langfilled Smith in their 1998a and 1998b papers believed that modern practices were complementary to the traditional ones. ${ }^{\text {vii }}$ On the contrary, Johnson (1994) viewed the modern techniques as substitutes for traditional ones. ${ }^{\text {vii }}$ But, Sharma, R. 2000 in his paper in response to article of Johnson \& Kaplan 1987 stated

Choice and selection between traditional and emergent management Practices is therefore particularly relevant for the business manager in a new millennium, as ultimately this decision could determine an organization's survival and success. ${ }^{\mathrm{ix}}$

To reconcile the above issues, it is important to notice that most traditional managerial/cost accounting techniques such as process costing, absorption costing, variable costing, budgeting, and cost profit analysis are basically cost classification, cost allocation, and cost behavior techniques. The modern practices and techniques, however, have their main concern and emphases on cost control and cost reduction. Activity analysis (ABC model) and classification of activities to value added and not value added (ABM model) are the examples of the above concern. It appears that both groups are important for the success of business enterprises. However, a question worth considering is the degree of usefulness of each group, especially from the view point of practitioners and academia.

Rob Sharma (2000) has attempted to rank various managerial/cost accounting techniques and practices in terms of their usefulness. In his study, he has selected 33 practices in management accounting (10 traditional, 17 emergent, and 6 other) and tried to determine the degree of their usefulness for managerial decision making purposes. Table 4 shows the ranking of 33 selected topics.

The outcomes of Rob Sharma' study suggested that the first 16 management accounting practices had a high level of benefit while the rest had a moderate benefit for managerial decision-making purposes. Among the top 
16 practices with high benefits, 10 practices fell under emergent management accounting practice, 4 under traditional practices and two under others. The conclusion reached in this study was that managers need to use traditional and non- traditional managerial accounting techniques in order to make better managerial decisions. ${ }^{\mathrm{x}}$ The Sharma 2000 study was a mail survey questionnaire of 1500 middle level accounting managers, selected randomly from the CPA membership list with a response rate of $22 \%$. This study reflected only the opinion of practitioners (CPAs). It did not reflect the opinions of academia.

In another study Hawkes, 1 c, Fowler, M. and Tan,L. M have asked both academia and practitioners about the importance of various managerial accounting topics and techniques. They tried to identify the gap between the opinion of academia and practitioners in their study. This study was conducted in New Zealand by using a mail questionnaire directed to academia and practitioners. The academia were selected from Tertiary Educational Institutes (TEIs) that had an Accounting Program while the practitioners were chosen randomly from 200 public and 100 private companies in New Zealand. The rate of response for practitioners was $24 \%$ and academia was $66.6 \%$. ${ }^{\mathrm{xi}}$

The outcome of the study supported the conclusions of previous studies and showed that practitioners still favor traditional and the academia favored emergent managerial/cost accounting techniques. In this study, six out of the top ten management accounting techniques selected by practitioners were among the traditional, while for the academia the top six techniques were among the emergent techniques as reported below:

Practitioners Choice

1) Cash flow management

2) Operational budgeting

3) Variance analysis

4) Capital budgeting

5) Product costing

6) Cost volume profit Analysis

\section{Academia Choice}

1) Behavioral implications

2) Activity based costing $A B C$

3) Activity based management ABM

4) Strategic management accounting

5) Customer profitability

6) Cost of quality

In the previously quoted study by Rob Sharma $(2000)^{\mathrm{xii}}$ the author also attempted to determine the impact of various factors such as organization size, type of industry (manufacturing and non manufacturing), and organizations strategy on the selection and ranking of management accounting practices. According to that study, business managers viewed emergent techniques as more contributory and beneficial than traditional techniques, especially for medium and large size firms. In addition, it was observed that for manufacturing firms both traditional and emergent practices had similar level of perceived benefits. But for non-manufacturing firms the emergent practices had higher levels of perceived benefits. In other words, traditional practices in non-manufacturing firms were perceived to offer lower level of benefits. In short, the results of this study indicated that organizations in the new millennium should adopt more holistic approach to management. Managers should utilize both traditional and non-traditional management accounting methods to make better managerial decisions. Size of companies was significant for emergent practices, while the type of industry was significant for traditional practices. ${ }^{\text {xii }}$

Similar studies have been also conducted outside of The U.S.A. In 1997 John Lowry and Christine Yap studied the practices of management/cost accounting in Australia. They used 659 Australia CPAs and ranked the issues and practices of managerial/cost accounting in Australia as reported in table 5 below. ${ }^{\text {xiv }}$ An important conclusion of this research was that the skills taught at universities were not those required in the workplace. This survey also suggested the existence of a gap between textbook materials and the actuality of management accounting work.

David Forsaith, Carol Tilt, and Maria Xydias (2001) in their study called The future of Management Accounting: A South Australian Perspective examined the accounting issues and practices by raising the following question regarding the managerial accounting practices in South Australia:

a) What do management accountants see as the current and future functions of management accounting? 
b) For being considered as management accountants, what do management accountants see as their current and future tasks?

c) What do management accountants see as the current and future skills required to perform these tasks /activities?

d) Do management accountants think there have been changes in the functions, tasks and skills of management accounting in the past 5 years?

According to this study the top five stated current and future primary functions of management accounting were reporting information provision, strategy, decision making, forecasting and planning, and budgeting and costing. In regard to the current and future "tasks and activity" for management accountants, budgeting and strategy planning received the major emphasis in this research. The "accounting systems and financial" was also reported as the single and most critical activity for management accountants in this study. This study further revealed quite clearly that those who worked in field of management accounting perceived their role as a changing one. The report pointed out that the required changes were mainly in the tasks that management accountants must undertake. ${ }^{\mathrm{xv}}$

Normah Omar and Rokiah Muda (2002) have examined the nature and characteristics of management accounting practices of Japanese companies in Malaysia. This survey involved a questionnaire technique and faceto-face interviews of one hundred Japanese companies in Kuala Lumpur. One of the findings of this survey was that two of the traditional managerial/cost accounting techniques, Standard/variance analysis and Budgeting were widely used by the Japanese companies in Malaysia (66\% and 100\%respectively). In addition to these two traditional techniques, the Japanese companies used some of the "modern techniques". Two most popular "new management accounting" techniques were Target costing and Just in Time. The study also revealed that, in general, the Japanese companies preferred to use those techniques which were "simple- to- understand".

Reviewing the accounting literatures, including those mentioned above, indicates that modern and emergent practices such as Just-In-Time (JIT), Activity-Based Costing (ABC), Activity-Based Management (ABM), Total Quality Management (TQM), Robotics, Total Quality Control and Zero Defects (TQC), Target Costing, Kaizen costing, Benchmarking, Value Chain and Supply Chain analysis and Balance Scorecards have received relatively good welcome from most academia and scholars. The practitioners, however, have not accepted the models wholeheartedly. This point was also revealed again in the most recent survey conducted by Hawker, Et.al in $2004{ }^{\text {xvi }}$ As was concluded in this study, educators' views regarding the importance of different managerial accounting topics differed from those of the practitioners. Educators viewed the ensuing four topics, (1) Behavioral Implications, (2) Activity Based Costing (ABC), (3) Performance Evaluation, and (4) Product Costing most important and consequently recommended them to be included in the accounting curriculum. In contrast, practitioners view (1) Cash Flow Management, (2) Operational Budgeting, (3) Variance Analysis, and (4) Performance Evaluation as the four most important topics.

\section{RESEARCH METHODOLOGY}

In order to gather the data for this research, questionnaires were mailed to educators and practitioners. These questionnaires surveyed participants' opinions about the usefulness of managerial/cost accounting techniques as well as skills and characteristics required for newly graduated management accountants.

\section{Research Questions}

1. Are the contemporary (emergent) techniques and developments in the managerial/cost accounting more important and useful than the old and traditional ones?

2. Is there a significant gap between the opinions of educators and practitioners regarding the importance and utility of various managerial/cost accounting techniques and topics? (Theory vs. practice)

3. If there is a significant gap between theory and practice, how could this gap be narrowed and possibly eliminated? 


\section{Hypotheses}

H 1: There is no statistically significant gap between the opinions of practitioners and educators regarding the usefulness of various managerial/cost accounting techniques.

H 2: There is no statistically significant difference between the usefulness of traditional and contemporary managerial/cost accounting techniques from the view of practitioners and educators.

H 3: There is no statistically significant influence of other factors such as respondents' age, education, size of company, etc. on the degree of usefulness of traditional vs. contemporary managerial/cost techniques.

H 4: Regarding the skills required for Management Accounting graduates, there is no statistically significant gap between the opinions of practitioners and educators.

H 5: Regarding the characteristics required for Management Accounting graduates, there is no statistically significant gap between the opinions of practitioners and educators.

\section{Sample Size}

The sample consisted of 150 accounting professors who taught managerial/cost accounting courses in the USA. The practitioners were selected from managers and controllers of companies operating in the USA. The sample size for this group originally represented almost $10 \%$ of the total companies listed in the New York Stock Exchange (NYSE). Due to the lack of responses from the selected companies listed in the NYSE, 100 additional managers and controllers from the membership list of the Institutes of Management Accounting were added to the practitioners' sample. The mailing of 150 questionnaires to academics resulted in 34 usable responses, giving a response rate of $22.7 \%$, while 300 questionnaires mailed to practitioners resulted in 29 usable responses, giving a response rate of $10 \%$.

\section{Survey Questionnaire}

The educators' questionnaire included a series of questions about demographic data, including age, teaching experience, current academic title, type and level of courses taught. The practitioners' questionnaire was similar, but in addition to the demographic questions such as background, age, education, number of years of experience in management accounting, and current job title, it included questions about their companies. These questions focused on total dollar sales, number of products or services, and the industry classification of their companies. Both groups were asked a series of other questions including the following:

- Level of degree of familiarity with different managerial/cost accounting topics

- $\quad$ Level of use of the various models and concepts

- $\quad$ Level of importance of each model and concept

- $\quad$ Various skills and characteristic

To facilitate the comparison of findings of this research with those of a similar research done in New Zealand by Hawker, Fowler and Tan (2004), every attempt was made to duplicate the research methodology that was used by those authors. The questionnaire used in this study was therefore adapted from Hawker et al. with some modifications. One of the modifications was that the practitioners were provided with a space to specify their degree of familiarity with a given managerial/cost accounting technique when ranking the level of usefulness of that technique. Because the practitioners might not be familiar with techniques included in the survey, it was necessary to include a measure of the degree of their familiarity. The reason for this modification was to determine the degree of reliability of the responses. The reliability of responses from those who have inadequate familiarity with the techniques could, indeed, be highly questionable. The other modification was the number of managerial/cost accounting techniques included in the questioner. The Hawker, Fowler and Tan questioner included only 28 techniques, while in this research questioner 10 additional techniques were included. 


\section{DATA COLLECTION AND DATA ANALYSIS}

Table (6) demonstrates the characteristics of 34 educators participated in this study. These characteristics are subclassified in terms of age, practical experience, teaching experience, current job title, course level and type of course taught. For some of the sub-classifications, one or two of the respondents failed to provide answers to a given question. As a result, the total number of responses dropped from 34 to 32 .

As can be seen in Table (6), 29.4\% of the participants were below 50 years of age, $55.9 \%$ were between 50 and 59 and $14.7 \%$ were over 60 years. Stated differently, about $70 \%$ of the educators participated in this study were over 50 years of age.

In regard to practical experience of the educators in Managerial/Cost Accounting, $90.9 \%$ of the participants had less than 5 years of experience (30 out of 33). Interestingly enough, in this category, 12 out of 30 reported zero years of practical experience.

The average practical experience for all 33 respondents was 3.5 years, while the average teaching experience was 16.5 years. This comparison indicates that educators who participated in this study had been involved mostly in teaching and rarely in practice.

As far as titles were concerned, $23.5 \%$ of the academia participants were associate professors and $52.9 \%$ full professors. Furthermore, $42.4 \%$ of them taught introductory accounting courses, 33.3\% intermediate, and 24.2\% advanced level.

Table (7) shows the demographics of the 29 practitioners who participated in this study. These practitioners are grouped according to their age, education, experience, sales and number of products of their companies, and their industry.

Out of 29 practitioners participating in this study, $55.1 \%$ were below 50 years, $24.1 \%$ were between 50 and 59 years and $20.8 \%$ were older than 60 years. With regard to their education, $58.6 \%$ had bachelor degrees and the remaining $41.4 \%$ had master's degrees. In addition, 17 of 29 participants had professional certificates including 10 CAPs, 3 CMAs and 4 other.

With regard to their accounting and managerial experience, $38.1 \%$ of 29 practitioners had more than 25 years of experience, $4.8 \%$ had between $21-25$ years and $19 \%$ between $16-20$ years, and $38.1 \%$ less than 15 years of experience.

The sales of the companies that the 29 participants worked for demonstrated a broad distribution. These companies represented basically all types of industries including personal and other service industries which ranked at the top with $24.1 \%$ of the total companies, followed by manufacturing with $17.2 \%$, property \& business services with $13.8 \%$, and finance \& insurance with $10.3 \%$. The number of products these companies produced was reported as: $53.7 \%$ produced 1 to 15 products, $35.7 \%$ produced more than 75 products, and only $10.7 \%$, which fell in the middle rank, produced 16-30 products. In other words, it was reported that a little over $1 / 3$ of the companies produced a significant number of products, namely more than 75 types.

\section{Data Analysis}

The ranking, in regard to their importance (Mean), for the 38 managerial/cost accounting techniques by the two groups of participants is reported in Table 8. For cross comparison purposes, two additional columns were included in table 8, called P/R (Practitioner Ranking) and A/R (Academic Ranking). From the first 10 top techniques selected by both groups reported in table 8,6 techniques were the same, indicating that both educators and practitioners considered them as the top ten important techniques in the managerial/cost accounting. These techniques are reported below: 


\begin{tabular}{llc}
$\mathbf{A} / \mathbf{R}=$ Academic Ranking & $\mathbf{P} / \mathbf{R}=\mathbf{P r a c t i t i o n e r}$ Ranking \\
\hline 1. & Ethical Issue & $\mathrm{A} / \mathrm{R}=7, \quad \mathrm{P} / \mathrm{R}=2$ \\
2. & Variance Analysis & $\mathrm{A} / \mathrm{R}=8, \quad \mathrm{P} / \mathrm{R}=3$ \\
3. & Operating Budgeting & $\mathrm{A} / \mathrm{R}=5, \quad \mathrm{P} / \mathrm{R}=4$ \\
4. & Product Costing & $\mathrm{A} / \mathrm{R}=3, \quad \mathrm{P} / \mathrm{R}=6$ \\
5. & Standard Costing & $\mathrm{A} / \mathrm{R}=10, \mathrm{P} / \mathrm{R}=8$ \\
6. & Performance Evaluation & $\mathrm{A} / \mathrm{R}=1, \quad \mathrm{P} / \mathrm{R}=7$ \\
\hline
\end{tabular}

\section{Comparative Analysis}

The results of this study were compared with those of Hawkes et al. study. This comparison showed closer similarities in practitioners' perceptions than academics' perceptions in two studies. For the academics, only 5 of the first 10 top techniques in both studies were ranked somewhat similarly. These five techniques were: Performance evaluation, Product costing, Activity-based costing, Operating budget, and Activity-based management. For more information, see Tables 9 and 10.

\section{Skills Of The Students}

In regard to the skills requirement by managerial/cost accounting students, this study showed that both educators and practitioners listed "Thinking" as the top skill. However, educators placed the Problem solving and Quantitative skills in second and third places, while practitioners put Listening and Writing skills in second and third place. Both group agreed that management, social and marketing skills were less important skills and ranked them $9^{\text {th }}$ and $11^{\text {th }}$ in their lists. Table 11 shows the details of the responses.

Comparison of the results of past studies with the result of this study indicated rather a similar conclusion. In both the Hawkes' et al. (2003) and Novin's (1990) studies, the "Thinking" was listed as the top required skill for management accountants followed by "problem solving" and "Listening" skills. Table 12 shows the comparison of the top three in different studies:

\section{Characteristics Of The Students}

The characteristics of managerial accounting graduate preferred by the educators and practitioners in this study, reported separately and combined, are presented in Tables 13. As reported in Table 13, the educators rated "Ethical awareness" as number one but practitioners rated "Common sense" as number one characteristic. Stated differently, "Common sense" and 'Ethical awareness" characteristics were included in the top three choices by both educators and practitioners, though with different ranking.

Comparison of the results of this study with those of the past indicated some similarity. Practitioners in Novin's study (1990) also rated "Common sense" at the top, followed by "Ethical awareness" and "Motivation". Hawkes" et al. study (2003) showed "Common sense", "Motivation" and "Professional attitude" as the top three Characteristics (Table 14).

One of the major finding in this study, compared to Hawkes et al. was the fact that "Ethical awareness", which was ranked number one by educators and number 3 by practitioners in this study, was rated low in Hawkes' study. In that study, it was ranked $5^{\text {th }}$ and $8^{\text {th }}$ by educators and practitioners respectively. This may indicate that the recent scandals in the business world such as Enron and WorldCom have had some positive impact on the opinion of educators and practitioners regarding the ethical behavior.

\section{Statistical Results Of Testing The Hypotheses}

Since the size of samples in this study was not large enough, 34 educators and 29 practitioners, the t-test was recommended only for the total variables. This recommendation was based on several reasons. First, running 
multiple concurrent t-test would inflate the Type I error rate. Second, we may need more subjects to include more variables in the analyses. As a rule of thumb, at lease 15 subjects is needed for each variable, therefore, due to the concern on the lack of power we decided to do the analyses on the total scores. Furthermore, for testing of hypothesis $\mathrm{HO} 3$, the correlation analysis rather than the t-test was deemed more appropriate. In short, the t-test was used for testing hypotheses $\mathrm{HO} 1, \mathrm{H} 02, \mathrm{H} 04, \mathrm{H} 05$ and the correlation analysis was used for hypothesis $\mathrm{H} 03$. At $95 \%$ confidence level, the $\mathrm{HO}$ 1, H0 2, H0 3, and H0 5 were accepted. At the above level of confidence, however, the $\mathrm{H} 04$ rejected. The following results were achieved after applying a correlation analysis to hypothesis $\mathrm{H} 3$.

\section{For Practitioners}

1) Age had influence on the selection of Traditional managerial/cost accounting techniques.

2) Education had influence on the selection of Contemporary managerial/cost accounting techniques.

3) The other factors such as Experience, Size of company, Type of industry, Number of products showed no significant influence on the selection of traditional and contemporary managerial/cost accounting techniques.

\section{For Educators}

1) Course level taught had influence on the selection of traditional managerial/cost accounting techniques.

2) Current job title had influence on the selection of contemporary managerial/cost accounting techniques.

3) The other factors such as Age, Practical experience, Teaching experience and Type of course showed no significant influence on the selection of traditional and contemporary managerial/cost accounting techniques.

\section{Detailed Hypothesis Analysis}

Null Hypothesis One (H 1): Independent samples tests regarding the usefulness of various managerial/cost accounting techniques showed that the null hypothesis one (H 1) was rejected only in 9 out of 38 techniques under consideration. In other words, the t-tests suggested that for the remaining 29 techniques, there was no statistically significant gap between the opinion of practitioners and educators regarding their usefulness.

The nine techniques, for which the null hypotheses were rejected, according to the independent analyses, were as follows:

1) Cash Flow Management

2) Cost Volume Profit (CVP)

3) Ethical Issues

4) Joint by Product Costing

5) Variance Analysis

6) Activity Based Costing

7) Activity Based Management

8) Activity Based Budgeting

9) Enterprise Resource Planning (ERP)

It should be mentioned that the above findings were supported also by Sharma (2000) in his study. ${ }^{\text {xvii }}$

Null Hypothesis two (H 2): The t-test applied to this hypothesis indicated that there was no statistically significant difference between the usefulness of traditional and contemporary managerial/cost accounting techniques from the view points of two groups of participants

Null Hypothesis three (H 3): This hypothesis was designed to find whether other factors such as age, education, experience, sales (reflecting the size of the companies), number of products, and the type of industry for practitioners; and age, practical experience, teaching experience, current job title, course level and type of course for 
educators, influence the degree of usefulness of traditional vs. contemporary managerial/cost Accounting techniques. The outcomes of this study indicate that among the above listed factors only a few had statistically significant influence on the degree of usefulness of managerial /cost accounting techniques. In other words, generally speaking there was no statistically significant influence of majority of other factors on the degree of usefulness of traditional vs. contemporary managerial/cost accounting techniques.

The above findings were contrary to those revealed in some of the previous studies. For instance, according to Emmanuel, Otley and Merchant (1991), the size of the company was the most important factor that influence the

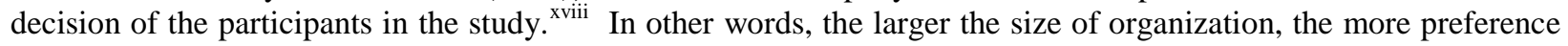
was given to the use of contemporary (emergent) techniques. It was perceived that organizations of larger size could substantially benefit more from an effective combination of traditional and emergent management accounting practice.

Null hypothesis four ( $\mathrm{H} 4)$ : According to the total variable t-test, this hypothesis was rejected, meaning that a statistically significant gap existed between the opinions of practitioners and educators regarding the skills requirement for management accounting graduates. However, based on the independent samples t-test for each skill, this hypothesis was accepted.

The above-mentioned finding based on the total t-test, (rejection of null hypothesis $\mathrm{H}$ 4) was supported by Lowry and Yap. ${ }^{\text {xix }}$ According to their study, the skills taught at universities were not those required in the workplace. In other words, their survey suggested a gap between textbook images and the actuality of management accounting work.

Null hypothesis five (H 5): The hypothesis H 5 could not be rejected according to both the total and independent samples t-tests. This can be interpreted that no statistically significant gap existed between the opinions of practitioner and educators regarding the required characteristics for management accounting graduates

\section{SUMMARY, CONCLUSION AND RECOMENDATIONS}

This study attempted to determine whether or not there was a significant difference between the opinions of academics and practitioners regarding the usefulness of traditional vs. contemporary managerial/cost accounting techniques. It also tried to determine the degree of influences of various factors such as age, education, position, size of company, number of products, type of industry and several others on the opinion of the educators and practitioners regarding the above issue. Another attempt that was made in this study was to acquire some information about the opinion of educators and practitioners regarding the degree of importance of eleven skills and ten characteristics for managerial accounting graduates. The pursuing conclusions are result of opinions of 34 educators and 29 practitioners participated in this study.

The outcomes of this study revealed that out of 38 managerial/cost accounting techniques presented in this research, 16 were rated high by all participants (Table 8). This ranking was based on the statistical Means calculated for the total of 63 participants in this study. Out of these 16 techniques, 12 were selected by both groups of educators and practitioners. These 12 techniques included Performance Evaluation, ranked 1 by academia \& 7 by practitioners (1\&7), Cost-Volume Profit (2\&15), Product Costing (3\&6), Activity-Based Costing (4\&12), Operating Budget (5\&4), Ethical Issues (7\&2), Variance Analysis (8\&3), Flexible Budgeting (9\&14), Standard Costing (10\&8), Job Costing (11\&8), Capital Budgeting (12\&8), and Customer Profitability Analysis (15\&10). The remaining 4 techniques that were not selected by both groups included Activity-Based Management (6\&18), Responsibility Accounting (14\&20), Strategic Management Accounting (16\&17), and Cash Flow Management (17\&1). Even though the latter 4 techniques were not included in the top 12, their ranks fell rather in the middle of the spectrum of 1 to 38 .

A close look at table 15 (the highly rated 16 techniques by both groups of participants) indicates that 9 of the techniques were traditional and 7 were contemporary. The traditional techniques included, Cost-Volume Profit Analysis, Product Costing, Operating Budget, Ethical Issues, Variance Analysis, Standard Costing, Job Costing, 
Capital Budgeting, and Cash Flow Management. The contemporary techniques consisted of Performance Evaluation, ABC, ABM, Flexible Budgeting, Responsibility Accounting, Customer Profitability, and Strategic Management Accounting.

In contrast to the above 16 techniques, from the 38 techniques evaluated in this study, seven techniques were among those which ranked very low and viewed the least important by both participants. These techniques, as reported in Table 8, included Agency Theory (35\&38), Linear Programming (38\&36), Environmental Cost Management (36\&33), Life Cycle Cost Management (32\&31), Regression Analysis (30\&30), Reciprocal Method of Cost Allocation (37\&37), and Joint/by Product Costing (34\&28).

The outcomes of the research, however, indicated that a few demographic factors have some influence on the decisions and rating of the participants. For practitioners, the factor of Age had influence on the selection of traditional and the factor of Education had influence on the selection of contemporary managerial/cost accounting techniques. For educators, the Course level taught had influence on the selection of traditional and the Current job title had influence on the selection of contemporary managerial/cost accounting techniques. Other demographic factors showed no significant effects on the selection of techniques. These results were different from those of previous studies, where size of the organization, number of products and type of industry had some effect on the degree of usefulness of traditional and contemporary managerial/cost accounting techniques

The outcomes of this study also revealed that from the 11 preferred skills for managerial/cost accounting graduates, the "thinking skill" was rated top by both the academics and practitioners (Table 12). It was, then, followed by "listing", "quantitative", "problem solving" and "writing" skills. The three skills that were ranked as less important by both groups were, "reading","speaking" and "microcomputer" skills. The least important skills by both groups were "management", "social", and "marketing" skills.

In regard to the issue of important characteristics for accounting graduates, the outcomes of this study indicated that both practitioners and educators selected "common sense", "motivation", "ethical awareness", and "intellectual capacity" as the top four important characteristics (Table 13). In contrast, "professional appearance", "assertiveness", and "pleasant personality" were the three characteristics selected by both groups as less important. Based on the above observations, the main conclusion reached by this research was that no significant differences existed between the opinions of practitioners and educators regarding the list of the most important managerial/cost accounting techniques in this study.

\section{RECOMMENDATIONS}

For a long time, the following criticisms have been received from both practitioners and educators about the usefulness of managerial/cost accounting techniques and practices. The practitioners have believed that educators usually develop new accounting techniques, which are highly theoretical and not easily and economically applicable by all companies. The educators, on the other hand, have believed that because of resistance to change, practitioners are not willing to try new techniques wholeheartedly.

The outcomes of this study have revealed some reconciliation between the above two conflicting believes. As was discussed before, practitioners and educators selected the same16 managerial/cost accounting techniques as the top rated techniques. Based on this outcome, therefore, it is recommended that these 16 techniques (Table 15) be included in the curriculum of business schools for introductory and intermediate managerial \& cost accounting courses.

Furthermore, there were four techniques (Behavioral implication, Transfer pricing, Balance scorecard, and Value chain), which received higher ratings by the educators than practitioners. We believe that Balance scorecard, and Value chain, are very important techniques and should be communicated more closely to practitioners.

Based on the other outcomes of this study, the following skills and characteristics are also recommended for greater emphasis and development at business schools in order to produce better accounting graduates: 
"thinking”, "listing”, “quantitative”, "problem solving” and "writing" skills; "common sense", "motivation", "ethical awareness", and "intellectual capacity".

The final recommendation of this study is directly related to accounting educators. Accounting faculties need to have more practical involvement with what they preach. According to the findings of this research, the average practical experience of educators in this study was 3.5 years, while their average teaching experience was 16.5 years. Some of these educators, surprisingly enough, had zero years of practical experience in accounting. This recommendation also was done by Zimmerman and Summon (2001). As was suggested in their study that today's business schools should encourage their faculties to conduct more practical and less theatrical research. This should narrow down the gap between theory and practices as well as the differences of opinion between practitioners and educators. $^{\mathrm{xx}}$

\section{LIMITATIONS AND SUGGESTIONS FOR FUTURE RESEARCH}

The first limitation in this study was a low rate of response. Only 34 educators and 29 practitioners responded to the questionnaires of this research. The second limitation was the interpretation of questions asked in this research and the understanding of some modern accounting techniques and technical terms, especially by practitioners. Even though a glossary of terms and accounting techniques was attached to the questionnaires, it appeared that some participants had difficulties with some of the terms. Consequently some misinterpretation is deemed to have occurred in the process.

\section{TABLES}

Table 1

Trend analysis of Managerial Accounting Practice

\begin{tabular}{|c|c|c|}
\hline Rough Time Estimate & Focus & Trend in Managerial Accounting \\
\hline Prior to 1950 & $\begin{array}{l}\text { Cost determination and Financial } \\
\text { control }\end{array}$ & Budgeting and Cost accounting system \\
\hline Mid 1960's & $\begin{array}{l}\text { Providing information needed for } \\
\text { management control }\end{array}$ & $\begin{array}{l}\text { Anthony's } 1965 \text { management control } \\
\text { framework }\end{array}$ \\
\hline 1970’s & Planning and control & $\begin{array}{l}\text { Contingency theory choice of } \\
\text { accounting and control techniques } \\
\text { depend upon circumstances }\end{array}$ \\
\hline Mid 1980’s & Reduction of waste & ABC, Strategic cost management etc. \\
\hline Mid 1990’s & Creating firm value & $\begin{array}{l}\text { Balance scorecard of leading economic } \\
\text { indicators MAS that address current } \\
\text { and Future strategic uncertainty }\end{array}$ \\
\hline
\end{tabular}

Table 2

Modern Management Accounting Practices

\begin{tabular}{|c|c|c|}
\hline Practices & Initiators & Year \\
\hline Activity Based Costing & Cooper \& Kaplen & $1991-1992$ \\
\hline Balance Scorecard & Kaplan\& Norton & 1992 \\
\hline Quality Costing & Deming & 1989 \\
& Oakland & 1991 \\
& Hill & 1997 \\
\hline Benchmarking & Petty & 1992 \\
\hline Strategic Planning & Bolin & NA \\
\hline Value Creation & Anthony & NA \\
\hline
\end{tabular}


Table 3

Management Accounting Issues

\begin{tabular}{|c|c|}
\hline Traditional Practice & Emergent Practice \\
\hline $\begin{array}{cl}\text { Budgeting System } \\
\text { - } & \text { Controlling Costs } \\
\text { - } & \text { Evaluating Manager Performance } \\
\text { - } & \text { Planning Cash Flow } \\
\text { - } & \text { Capital Budgeting Techniques } \\
\text { - } & \text { Residual income (Interest adjusted profit) } \\
\text { Costing Methods } \\
\text { - } & \text { Absorption Costing } \\
\text { - } \quad \text { Variable Costing } \\
\text { - Job Order Costing } \\
\text { - Process Costing } \\
\text { - Standard Costing } \\
\text { Products Analysis Cost Allocation } \\
\\
\text { - Cost Volume Profit Analysis } \\
\text { - Product Profitability }\end{array}$ & 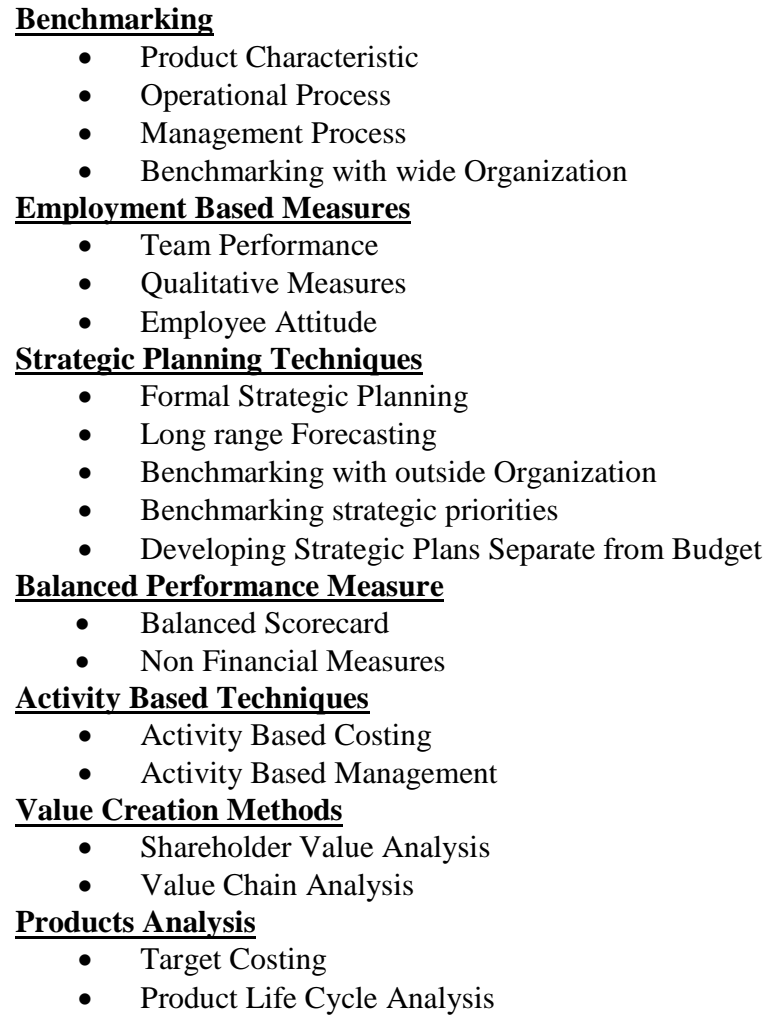 \\
\hline
\end{tabular}


Table 4

Ranking of Management Accounting Practices

\begin{tabular}{|c|c|c|c|c|c|}
\hline Ranking & Topics & Traditional & & Emergent & Other \\
\hline 1 & Formal Strategic Planning & & & $*$ & \\
\hline 2 & Budgeting system for controlling costs & $*$ & & & \\
\hline 3 & Strategic plans developed together with budgets & & & * & \\
\hline 4 & Detailed budgeting for planning financial position & $*$ & & & \\
\hline 5 & Detailed budgeting for planning cash flows & $*$ & & & \\
\hline 6 & Balanced Scorecard & & $*$ & & \\
\hline 7 & Non Financial Measures & & $*$ & & \\
\hline 8 & Budgeting systems for evaluating managers performance & $*$ & & & \\
\hline 9 & Benchmarking of strategic priorities & & & $*$ & \\
\hline 10 & Benchmarking of operating processes & & & $*$ & \\
\hline 11 & Long Range Forecasting & & & $*$ & \\
\hline 12 & Benchmarking of Management Processes & & & $*$ & \\
\hline 13 & Performance evaluation based on qualitative measures & & & * & \\
\hline 14 & Performance evaluation based on team performance & & & * & \\
\hline 15 & Benchmarking carried out within the wider organization & & & & $*$ \\
\hline 16 & Customer satisfaction surveys & & & & * \\
\hline 17 & Product Profitability analysis & $*$ & & & \\
\hline 18 & Capital Budgeting & & & & * \\
\hline 19 & Employee attitude measures & & $*$ & & \\
\hline 20 & Benchmarking with outside organizations & & $*$ & & \\
\hline 21 & Activity Based Costing & & $*$ & & \\
\hline 22 & Cost Volume Profit Analysis & $*$ & & & \\
\hline 23 & Activity Based Management & & & $*$ & \\
\hline 24 & Developing strategic plans separate from budgets & & & & $*$ \\
\hline 25 & Benchmarking of product characteristics & & & $*$ & \\
\hline 26 & Ongoing supplier evaluations & & & & $*$ \\
\hline 27 & Shareholder value analysis & & & $*$ & \\
\hline 28 & Variable costing & $*$ & & & \\
\hline 29 & Value Chain Analysis & & & $*$ & \\
\hline 30 & Target Costing & $*$ & & & \\
\hline 31 & Absorption Costing & * & & & \\
\hline 32 & Residual Income (e.g. Interest adjusted profit) & & & $*$ & \\
\hline 33 & Product Life cycle analysis & & & & \\
\hline
\end{tabular}

Table 5

Respondents' Stipulation of High-Priority Topics*

\begin{tabular}{|c|c|c|c|c|}
\hline & \% & & \\
\hline Communication & $\mathbf{8 0 . 8}$ & Receivables control & $\mathbf{3 5 . 1}$ \\
\hline Spreadsheet modeling & $\mathbf{7 0 . 5}$ & & Flexible budgeting variances & $\mathbf{3 3 . 6}$ \\
\hline Staff management & $\mathbf{6 9 . 3}$ & Payroll control & $\mathbf{2 4 . 7}$ \\
\hline G/L processing & $\mathbf{6 3 . 5}$ & Transfer pricing & $\mathbf{1 6 . 6}$ \\
\hline Computer support & $\mathbf{6 2 . 0}$ & CVP formula & $\mathbf{1 3 . 1}$ \\
\hline Taxation knowledge & $\mathbf{4 7 . 8}$ & EOQ model & $\mathbf{6 . 6}$ \\
\hline Payables control & $\mathbf{3 7 . 8}$ & Regression analysis & $\mathbf{5 . 0}$ \\
\hline
\end{tabular}


Table 6

Educators' Demography

Age

\begin{tabular}{|c|c|c|c|}
\hline Years & Frequency & \% & Cumu \\
\hline $30-39$ & 4 & 11.8 & 12 \\
\hline $40-49$ & 6 & 11.76 & 29 \\
\hline $50-59$ & 19 & 55.9 & 85 \\
\hline Over 60 & 5 & 14.7 & 100 \\
\hline Total & 34 & 100 & \\
\hline
\end{tabular}

Teaching Experience

\begin{tabular}{|c|c|c|c|}
\hline Year & Frequency & \% & Cumu \\
\hline $0-5$ & 3 & 9.1 & 9.1 \\
\hline $6-10$ & 10 & 30.3 & 39.4 \\
\hline $11-15$ & 3 & 9.1 & 48.5 \\
\hline $16-20$ & 5 & 15.2 & 63.7 \\
\hline $21-25$ & 6 & 18.2 & 82.9 \\
\hline $26+$ & 6 & 18.2 & 100 \\
\hline Total & 33 & 100 & \\
\hline
\end{tabular}

Course Level Taught

\begin{tabular}{|c|c|c|c|}
\hline & Frequency & \% & Cumu \\
\hline Introductory & 14 & 42.4 & 42 \\
\hline Intermediate & 11 & 33.3 & 76 \\
\hline Advanced & 8 & 24.2 & 100 \\
\hline Total & 33 & 100 & \\
\hline
\end{tabular}

Practical Experience

\begin{tabular}{|c|c|c|c|}
\hline Years & Frequency & \% & Cumu \\
\hline $0-5$ & 30 & 90.9 & 91 \\
\hline $6-10$ & 1 & 3.03 & 94 \\
\hline $11-15$ & 1 & 3.03 & 97 \\
\hline $26+$ & 1 & 3.03 & 100 \\
\hline Total & 33 & 100 & \\
\hline
\end{tabular}

Current Job

\begin{tabular}{|c|c|c|c|}
\hline & Freq & \% & Cumu \\
\hline Assistant Professor & 8 & 23.5 & 23.5 \\
\hline Associated Professor & 8 & 23.5 & 47.0 \\
\hline Full Professor & 18 & 53.0 & 100 \\
\hline & & & \\
\hline & & & \\
\hline & & & \\
\hline Total & 34 & 100 & \\
\hline
\end{tabular}

Type of Course Taught

\begin{tabular}{|c|c|c|c|}
\hline & Frequency & \% & Cumu \\
\hline Core & 29 & 90.6 & 91 \\
\hline Elective & 3 & 9.38 & 100 \\
\hline & & & \\
\hline Total & 32 & 100 & \\
\hline
\end{tabular}


Table 7

Practitioner Participant's Demography

Age

\begin{tabular}{|c|c|c|c|}
\hline Years & Frequency & \% & Cumu \\
\hline $30-39$ & 7 & 24.1 & 24.1 \\
\hline $40-49$ & 9 & 31 & 55.2 \\
\hline $50-59$ & 7 & 24.1 & 79.3 \\
\hline Over 60 & 6 & 20.7 & 100 \\
\hline Total & 29 & 100 & \\
\hline
\end{tabular}

Experience

\begin{tabular}{|c|c|c|c|}
\hline Years & Frequency & \% & Cumu \\
\hline $0-5$ & 3 & 14.3 & 14.3 \\
\hline $6-10$ & 2 & 9.52 & 23.8 \\
\hline $11-15$ & 3 & 14.3 & 38.1 \\
\hline $16-20$ & 4 & 19.0 & 57.1 \\
\hline $21-25$ & 1 & 4.76 & 61.9 \\
\hline Over 25 & 8 & 38.1 & 100 \\
\hline & & & \\
\hline & & & \\
\hline & & & \\
\hline Total & 21 & 100 & \\
\hline
\end{tabular}

\section{Number of product}

\begin{tabular}{|c|c|c|c|}
\hline Items & Frequency & $\%$ & Cumu \\
\hline $1-15$ & 15 & 53.6 & 53.6 \\
\hline $16-30$ & 3 & 10.7 & 64.3 \\
\hline $31-74$ & 0 & 0 & 64.3 \\
\hline $75+$ & 10 & 35.7 & 100 \\
\hline & & & \\
\hline & & & \\
\hline & & & \\
\hline & & & \\
\hline & & & \\
\hline & & & \\
\hline & & & \\
\hline Total & 28 & 100 & \\
\hline
\end{tabular}

\begin{tabular}{|c|c|c|c|}
\hline Degree & Frequency & \% & Cumu \\
\hline Bachelors & 17 & 58.6 & 58.6 \\
\hline Masters & 12 & 41.4 & 100 \\
\hline & & & \\
\hline Total & & & \\
\hline & 29 & 100 & \\
\hline
\end{tabular}

Sales of the Organization

\begin{tabular}{|c|c|c|c|}
\hline Amount & Frequency & \% & Cumu \\
\hline Less than $\$ 100,000$ & 1 & 3.6 & 3.6 \\
\hline \$100,000-\$250,000 & 3 & 10.7 & 14.3 \\
\hline \$250,000-\$1 mill & 1 & 3.6 & 17.9 \\
\hline \$1 mill- \$ 5mill & 3 & 10.7 & 28.6 \\
\hline \$ 5mill- \$25 mill & 4 & 14.3 & 42.9 \\
\hline \$25 mill-\$100 mill & 3 & 10.7 & 53.6 \\
\hline \$100 mill-\$500 mill & 1 & 3.6 & 57.1 \\
\hline \$500 mill-\$1 bill & 4 & 14.3 & 71.4 \\
\hline \$1 bill and above & 8 & 28.6 & 100 \\
\hline Total & 28 & 100 & \\
\hline
\end{tabular}

Industry

\begin{tabular}{|c|c|c|c|}
\hline Type & Freq & \% & Cumu \\
\hline Agriculture, Forestry & 2 & 6.9 & 6.9 \\
\hline Manufacturing & 5 & 17.2 & 24.1 \\
\hline Electricity, Gas, Water & 2 & 6.9 & 31.0 \\
\hline Construction & 1 & 3.5 & 34.5 \\
\hline Accommodation, Cafes, Restaurants & 1 & 3.5 & 38.0 \\
\hline Communication Services & 1 & 3.5 & 41.5 \\
\hline Finance \& Insurance & 3 & 10.3 & 51.8 \\
\hline Property \& Business Services & 4 & 13.8 & 65.6 \\
\hline Gov. Administration \& Defense & 2 & 6.9 & 72.5 \\
\hline Health \& Community Services & 1 & 3.5 & 76.0 \\
\hline Personal \& Other Services & 7 & 24.1 & 100 \\
\hline Total & 29 & 100 & \\
\hline
\end{tabular}


Table 8

Managerial/Cost Accounting Techniques

Cross Ranking Academics vs. Practitioners

\begin{tabular}{|c|c|c|c|c|c|c|c|c|c|}
\hline & Academics & & & & & Practitioners & & & \\
\hline Rank & Contemporary $=\mathrm{C}$ & $\mathbf{N}$ & M Mean & $\mathbf{P} / \mathbf{R}$ & Rank & Contemporary $=\mathrm{C}$ & $\mathbf{N}$ & Mean & $\mathbf{A} / \mathbf{R}$ \\
\hline 1 & Performance evaluation & 34 & 4.41 & 7 & 1 & Cash flow management & 29 & 4.52 & 17 \\
\hline 2 & Cost-volume profit & 34 & 4.29 & 15 & 2 & Ethical issues & 29 & 4.38 & 7 \\
\hline 3 & Product costing & 34 & 4.24 & 6 & 3 & Variance analysis & 29 & 4.31 & 8 \\
\hline 4 & Activity Based Costing C & 34 & 4.12 & 12 & 4 & Operational budgeting & 29 & 4.28 & 5 \\
\hline 5 & Operational budgeting & 34 & 4.03 & 4 & 5 & Capital budgeting & 29 & 4.17 & 12 \\
\hline 6 & Activity Based Management C & 34 & 3.88 & 18 & 6 & Product costing & 29 & 4.17 & 3 \\
\hline 7 & Ethical issues & 34 & 3.82 & 2 & 7 & Performance evaluation & 27 & 3.96 & 1 \\
\hline 8 & Variance analysis & 34 & 3.79 & 3 & 8 & Standard Costing & 28 & 3.75 & 10 \\
\hline 9 & Flexible Budgeting & 34 & 3.74 & 14 & 9 & Job Costing & 29 & 3.69 & 11 \\
\hline 10 & Standard Costing & 34 & 3.65 & 8 & 10 & Customer profitability $\mathrm{C}$ & 29 & 3.66 & 15 \\
\hline 11 & Job Costing & 34 & 3.59 & 9 & 11 & Activity Based Budgeting C & 28 & 3.46 & 29 \\
\hline 12 & Capital budgeting & 33 & 3.58 & 5 & 12 & Activity Based Costing C & 27 & 3.44 & 4 \\
\hline 13 & Behavioral implications & 34 & 3.53 & 21 & 13 & Variable/Absorption costing & 28 & 3.39 & 21 \\
\hline 14 & Responsibility accounting & 34 & 3.5 & 20 & 14 & Flexible Budgeting & 29 & 3.38 & 9 \\
\hline 15 & Customer profitability $\mathrm{C}$ & 34 & 3.47 & 10 & 15 & Cost-volume profit & 29 & 3.38 & 2 \\
\hline 16 & $\begin{array}{l}\text { Strategic management } \\
\text { accounting } C\end{array}$ & 33 & 3.39 & 17 & 16 & Economic value added $\mathrm{C}$ & 27 & 3.37 & 23 \\
\hline 17 & Cash flow management & 34 & 3.38 & 1 & 17 & $\begin{array}{c}\text { Strategic management } \\
\text { accounting } \mathrm{C}\end{array}$ & 27 & 3.37 & 16 \\
\hline 18 & Balanced Scorecard C & 34 & 3.24 & 24 & 18 & Activity Based ManagementC & 29 & 3.31 & 6 \\
\hline 19 & Value chain concept $\mathrm{C}$ & 34 & 3.12 & 32 & 19 & Costs of quality $\mathrm{C}$ & 29 & 3.28 & 26 \\
\hline 20 & Transfer pricing & 33 & 3.09 & 22 & 20 & Responsibility accounting & 29 & 3.24 & 14 \\
\hline 21 & Variable/Absorption costing & 34 & 3.09 & 13 & 21 & Behavioral implications & 28 & 3.18 & 13 \\
\hline 22 & Just in time effects (JIT) C & 34 & 3.09 & 29 & 22 & Transfer pricing & 28 & 3.18 & 20 \\
\hline 23 & Economic value added $\mathrm{C}$ & 34 & 3.06 & 16 & 23 & Enterprise Resource Planning C & 27 & 3.15 & 33 \\
\hline 24 & Target Costing $\mathrm{C}$ & 34 & 2.97 & 27 & 24 & Balanced Scorecard C & 27 & 3.11 & 18 \\
\hline 25 & Process Costing & 34 & 2.94 & 25 & 25 & Process Costing & 28 & 3.11 & 25 \\
\hline 26 & Costs of quality $\mathrm{C}$ & 34 & 2.91 & 19 & 26 & Direct method cost allocation & 29 & 3.07 & 28 \\
\hline 27 & Theory of Constraints C & 34 & 2.91 & 34 & 27 & Target Costing $\mathrm{C}$ & 27 & 3.04 & 24 \\
\hline 28 & Direct method cost allocation & 34 & 2.76 & 26 & 28 & Joint / by product/ costing & 29 & 3 & 31 \\
\hline 29 & Activity Based Budgeting C & 33 & 2.73 & 11 & 29 & Just in time effects (JIT) C & 28 & 3 & 22 \\
\hline 30 & Regression analysis & 34 & 2.56 & 30 & 30 & Regression analysis & 29 & 2.79 & 30 \\
\hline 31 & Joint / by product/ costing & 34 & 2.5 & 28 & 31 & Life cycle cost management $\mathrm{C}$ & 28 & 2.71 & 32 \\
\hline 32 & Life cycle cost management $\mathrm{C}$ & 33 & 2.45 & 31 & 32 & Value chain concept $\mathrm{C}$ & 27 & 2.67 & 19 \\
\hline 33 & $\begin{array}{l}\text { Enterprise Resource Planning } \\
(\mathrm{ERP}) \ldots \mathrm{C}\end{array}$ & 34 & 2.35 & 23 & 33 & $\begin{array}{c}\text { Environment cost management } \\
\text { C }\end{array}$ & 28 & 2.64 & 36 \\
\hline 34 & Step Down Method Allocation & 34 & 2.29 & 35 & 34 & Theory of Constraints C & 27 & 2.59 & 27 \\
\hline 35 & Agency Theory C & 34 & 2.21 & 38 & 35 & $\begin{array}{c}\text { Step down method cost } \\
\text { allocation }\end{array}$ & 28 & 2.57 & 34 \\
\hline 36 & $\begin{array}{c}\text { Environment cost management } \\
\mathrm{C}\end{array}$ & 34 & 2.18 & 33 & 36 & Liner programming & 29 & 2.52 & 38 \\
\hline 37 & Reciprocal method allocation & 34 & 2 & 37 & 37 & Reciprocal method allocation & 27 & 2.41 & 37 \\
\hline 38 & Liner programming & 34 & 2 & 36 & 38 & Agency Theory $\mathrm{C}$ & 26 & 2.15 & 35 \\
\hline
\end{tabular}


Table 9

Practitioners' Perceptions and Ranking

\begin{tabular}{|c|c|c|c|c|c|c|}
\multicolumn{4}{c}{ This Study } & \multicolumn{2}{c}{ Hawkes Study } \\
\hline & Techniques & Rank & Mean & Mean \\
\hline 1 & Cash flow management & 1 & 4.52 & & 1 & 4.29 \\
\hline 2 & Variance analysis & 3 & 4.31 & & 3 & 4.14 \\
\hline 3 & Operating budgeting & 4 & 4.28 & & 2 & 4.24 \\
\hline 4 & Capital budgeting & 5 & 4.17 & & 5 & 3.97 \\
\hline 5 & Product costing & 6 & 4.17 & & 8 & 3.88 \\
\hline 6 & Performance evaluation & 7 & 3.96 & & 4 & 4.06 \\
\hline 7 & Customer profitability & 10 & 3.66 & & 7 & 3.91 \\
\hline
\end{tabular}

Table 10

Educators' Perception and Ranking

\begin{tabular}{|c|c|c|c|c|c|}
\hline & & \multicolumn{2}{|c|}{$\begin{array}{c}\text { This Study } \\
2004\end{array}$} & \multicolumn{2}{|c|}{$\begin{array}{c}\text { Hawkes Study } \\
2003\end{array}$} \\
\hline & Techniques & Rank & Mean & Rank & Mean \\
\hline 1 & Performance evaluation & 1 & 4.52 & 3 & 4.06 \\
\hline 2 & Product costing & 3 & 4.31 & 4 & 4.27 \\
\hline 3 & Activity based costing & 4 & 4.28 & 2 & 4.35 \\
\hline 4 & Operating budgeting & 5 & 4.17 & 5 & 3.83 \\
\hline 5 & Activity based management & 6 & 4.17 & 6 & 3.83 \\
\hline
\end{tabular}

Table 11

Skills Required For Management Accountants

\begin{tabular}{|c|c|c|c|c|}
\hline Academics & & & \\
\hline Rank & Skill & N & Mean & $\begin{array}{c}\text { Prac. } \\
\text { rank }\end{array}$ \\
\hline 1 & Thinking & 34 & 4.79 & 1 \\
\hline 2 & Problem solving & 34 & 4.74 & 4 \\
\hline 3 & Quantitative & 34 & 4.5 & 5 \\
\hline 4 & Listening & 34 & 4.5 & 2 \\
\hline 5 & Reading & 34 & 4.44 & 7 \\
\hline 6 & Writing & 34 & 4.35 & 3 \\
\hline 7 & Speaking & 34 & 4.29 & 6 \\
\hline 8 & Microcomputer & 34 & 4.26 & 8 \\
\hline 9 & Management & 34 & 4.24 & 10 \\
\hline 10 & Social & 34 & 3.91 & 9 \\
\hline 11 & Marketing & 34 & 3.03 & 11 \\
\hline
\end{tabular}

\begin{tabular}{|c|c|c|c|c|}
\hline Rank & Practitioners & & & \\
\hline 1 & Skill & N & Mean & $\begin{array}{c}\text { Acad. } \\
\text { rank }\end{array}$ \\
\hline 2 & Thinking & 29 & 4.79 & 1 \\
\hline 3 & Listening & 29 & 4.72 & 4 \\
\hline 4 & Writing & 29 & 4.52 & 6 \\
\hline 5 & Problem solving & 29 & 4.52 & 2 \\
\hline 6 & Quantitative & 28 & 4.5 & 3 \\
\hline 7 & Speaking & 29 & 4.14 & 7 \\
\hline 8 & Meading & 29 & 4.07 & 5 \\
\hline 9 & Socrocomputer & 29 & 4.03 & 8 \\
\hline 10 & Management & 29 & 3.97 & 10 \\
\hline 11 & Marketing & 29 & 3.83 & 9 \\
\hline
\end{tabular}

Table 12

Top Three Skills

Practitioners' Perception

\begin{tabular}{|c|c|c|c|}
\hline Rank & This study (2004) & Hawkes study (2003) & Novin study (1990) \\
\hline 1 & Thinking & Thinking & Thinking \\
\hline 2 & Listening & Problem solving & Problem solving \\
\hline 3 & Writing & Listening & Listening \\
\hline
\end{tabular}


Table 13

Academics \& Practitioners Cross Ranking of Characteristics Required For Management Accounting Graduates

\begin{tabular}{|c|c|c|c|c|}
\hline & \multicolumn{4}{|c|}{ Academics } \\
\hline Rank & & $\mathbf{N}$ & Mean & P/R \\
\hline 1 & Ethical awareness & 34 & 4.74 & 3 \\
\hline 2 & Common sense & 34 & 4.56 & 1 \\
\hline 3 & Professional attitude & 34 & 4.5 & 6 \\
\hline 4 & Motivation & 34 & 4.44 & 2 \\
\hline 5 & Intellectual capacity & 34 & 4.26 & 4 \\
\hline 6 & Confidence & 34 & 4.03 & 5 \\
\hline 7 & Leadership & 34 & 3.76 & 7 \\
\hline & Professional & & & \\
8 & appearance & 34 & 3.74 & 8 \\
\hline 9 & Assertiveness & 34 & 3.62 & 10 \\
\hline 10 & Pleasant personality & 34 & 3.59 & 9 \\
\hline
\end{tabular}

\begin{tabular}{|c|c|c|c|c|}
\hline & \multicolumn{4}{|c|}{ Practitioners } \\
\hline Rank & & $\mathbf{N}$ & Mean & $\mathbf{A} / \mathbf{R}$ \\
\hline 1 & Common sense & 29 & 4.83 & 2 \\
\hline 2 & Motivation & 29 & 4.48 & 4 \\
\hline 3 & Ethical awareness & 29 & 4.34 & 1 \\
\hline 4 & Intellectual capacity & 29 & 4.31 & 5 \\
\hline 5 & Confidence & 29 & 4.31 & 6 \\
\hline 6 & Professional attitude & 29 & 4.28 & 3 \\
\hline 7 & Leadership & 29 & 4.24 & 7 \\
\hline & Professional & & & \\
8 & appearance & 29 & 3.86 & 8 \\
\hline 9 & Pleasant personality & 29 & 3.72 & 10 \\
\hline 10 & Assertiveness & 29 & 3.69 & 9 \\
\hline \multicolumn{4}{|c}{}
\end{tabular}

Table 14

Comparison of Top Three Characteristics Based On Different Studies

\begin{tabular}{|c|c|c|c|}
\hline Rank & $\begin{array}{c}\text { This study } \\
(\mathbf{2 0 0 4})\end{array}$ & $\begin{array}{c}\text { Hawkes study } \\
(\mathbf{2 0 0 3 )}\end{array}$ & $\begin{array}{c}\text { Novin study } \\
(\mathbf{1 9 9 0 )}\end{array}$ \\
\hline 1 & Common sense & Common sense & Common sense \\
\hline 2 & Motivation & Motivation & Ethical awareness \\
\hline 3 & Ethical awareness & Professional attitude & Motivation \\
\hline
\end{tabular}

Table 15

Traditional/ Contemporary Techniques-Rankings \& Mean

\begin{tabular}{|c|c|c|c|c|c|c|c|}
\hline \multirow[t]{2}{*}{$\#$} & \multirow[b]{2}{*}{ Techniques/skill/char. } & \multicolumn{2}{|c|}{ Academics } & \multicolumn{2}{|c|}{ Practitioners } & \multicolumn{2}{|c|}{ Total } \\
\hline & & Mean & Rank & Mean & Rank & Mean & Rank \\
\hline 1 & Activity Based Costing & 4.12 & 4 & 3.44 & 12 & 3.82 & 9 \\
\hline 2 & Standard Costing & 3.65 & 10 & 3.75 & 8 & 3.69 & 10 \\
\hline 3 & Cost-volume profit & 4.29 & 2 & 3.38 & 15 & 3.87 & 7 \\
\hline 4 & Performance evaluation & 4.41 & 1 & 3.96 & 7 & 4.21 & 3 \\
\hline 5 & Operational budgeting & 4.03 & 5 & 4.28 & 4 & 4.14 & 5 \\
\hline 6 & Capital budgeting & 3.58 & 12 & 4.17 & 5 & 3.85 & 8 \\
\hline 7 & Cash flow management & 3.38 & 17 & 4.52 & 1 & 3.90 & 6 \\
\hline 8 & Product costing & 4.24 & 3 & 4.17 & 6 & 4.21 & 4 \\
\hline 9 & Job Costing & 3.59 & 11 & 3.69 & 8 & 3.63 & 11 \\
\hline 10 & Responsibility accounting & 3.50 & 14 & 3.24 & 20 & 3.38 & 15 \\
\hline 11 & Activity Based Management & 3.88 & 6 & 3.31 & 18 & 3.62 & 12 \\
\hline 12 & Variance analysis & 3.79 & 8 & 4.31 & 3 & 4.03 & 2 \\
\hline 13 & Ethical issues & 3.82 & 7 & 4.38 & 2 & 4.08 & 1 \\
\hline 14 & Customer profitability analysis & 3.47 & 15 & 3.66 & 10 & 3.56 & 14 \\
\hline 15 & Strategic management accounting & 3.39 & 16 & 3.37 & 17 & 3.38 & 16 \\
\hline 16 & Flexible Budgeting & 3.74 & 9 & 3.38 & 14 & 3.57 & 13 \\
\hline
\end{tabular}

\section{REFERENCES}

1. Anikkal, J. (1993), Exploring New Zealand Manufacturing, Accountants Journal, July, p.28-31.

2. Ansari, A. Bell, J., Klammer, T. and Lawrence, C.(1997), Management accounting in the Age of Lean Production A modular Series Management Accounting, Richard D. Irwin p. 5-8. 
3. Albrecht, W.S. \& Sack, R.J. (2004), Accounting Education: Charting the Course through a Perfidious Future. Accounting Education Series Volume No 16.

4. Barker, M. (1996), Management Accounting Future: Part November, p.32-54.

5. Bedford Committee, (1986): Future Accounting Education: Preparing For the Expanding Profession.

6. Beiges Professional Services Form, (1989), White Paper, Perceptions on Education for Success in Accounting Profession.

7. Brink H.V.D., and His Five Co-Authors (2001), Teaching Management Accounting In a CompetenciesBased Fashion, Open University of The Netherlands.

8. Broome, W.O. \& Morris, M.H. (2003), Multi-Entity Partnering in Accounting Education: Narrowing The GAP Between The Profession and Academic, University of Virginia \& University of Notre Dame.

9. Burkett, W.P. (1989), The Demand for and Supply of Management Accounting Function: A Delphi Study, Task Force for Accounting Education in Australia.

10. Chenhall, R.H. \& Langfield-Smith, K. (1998), Adoption and Benefits of Management Accounting Practices: An Australian Study, Management Accounting Research, 1998, pp1-19.

11. Chenhall, R.H. \& Langfield-Smith, K., (1998), the Relationship between Strategic Priorities. Management Techniques and Management Accounting: An Empirical Investigation Using a System Approach, Accounting Organization and Society Vol. 23 No. 3 pp 243-268.

12. Cooper, R. (2000), Cost Management: From Frederick Taylor to the Present. Journal of Cost Management (September-October), p.4-9.

13. CPA Vision Project: Focus on the Horizon (1998).

14. Creese, R.C. (2002), Cost Management in Lean Manufacturing Enterprises and the Effect upon Small and Medium Enterprises, Forth SMESME International Conference.

15. Denshi, J. \& Zimmerman, J. (2000), Research vs. Teaching: A Long-Term Perspective, Accounting Horizon 14.

16. Drury, C., (1998), Recent and Future Developments in Management Accounting, unpublished Article. See www.google.com.

17. Dyer, J.L. (1999) Accounting Education on the Threshold of a New Country, the Government Accounting Journal 48(4), p.40-47.

18. Emmanuel, C. Atley, D. \& Merchant, K (.2001), Accounting for Management Control, London, Chapman \& Hall.

19. Forsaith, D., Tilt, C. \& Xydias, M. (n.d.) The Future of Management Accounting: A South Australian Perspective School of Commerce, Flinders University Research Paper Series: 03-2.

20. Franciso, B., Kelly, A. (2002) Beyond Albrecht and Sack: A comparison of accounting professionals and college students.

21. Gabbin, A.L., (2002), the Crisis in Accounting Education, Journal of Accountancy (April): 81-86.

22. Harngren, C.T. (1989), Cost and Management Accounting: Yesterday and Today Journal of Management Accounting Research (1), p.21-23.

23. Hawkes, L., Fowler, M.B. \& Tan, L.M. (2004), Management Accounting Curricula: Shaking a Balance between the View of Educators and Praditioners, Accounting Education, (March) Vol. 13, p. 3-28.

24. IMA Study, (1999), Counting More, Counting Less.

25. IMA Study, (1996), the Practice Analysis of Management Accounting.

26. IMA Study, (1994), What Corporate America Wants in Entry Level Accountants.

27. Ittner, C.D. \& Larcker, D.F., (2001), Assessing Empirical Research in Management Accounting: A ValueBased Management Perspective. Journal of Accounting and Economics (32): 349-410.

28. Jeff Ords, R., Scheidt, M., \& Thibodaux, G.M., (2000), Securing the Future. Journal of Accountancy (February): 49-53.

29. Johnson, H.T. \& Kaplan, R.S., (1987), Relevance Lost: The Rise and Fall of Management Accounting (Boston: Harvard Business School Press).

30. Johnson H.T., (1992), Relevance Regained: From Top Down Control to Bottom Up Empowerment New York Free Press.

31. Kaplan R.S. (1998) Innovation Action Research: Creating New Management Theory And Practice. Journal of Management Accounting Research (10) pp. 89-118.

32. Kharbanda, O.P. (1992), Japan's Lesson for West CMA Magazine Vol. 66 Issue 1 pp. 26-28. 
33. Laitinen, E. (2001), Future Management Accounting: Preliminary Proportions with Survey Evidence.

34. Morgan, G. \& Sturdy, A. (2000), Beyond Organizational Change: Structure Discourse and Power in UK Financial Sciences Macmillan Press, London.

35. Muda, R. Omar,N. (2002)Study on Management Accounting Practices in Japanese Companies in Malaysia: Exploratory Evidence University Technology Malaysia.

36. Norvin, A. M. \& Meonske, N. (2001), Partnership between Practitioners and Accounting Faculty: Opportunities and Obstacles. The National Public Accountant (April): 17-19.

37. Shafer, W. \& Putman, (1998) A. The Case against Technical Specialization in Undergraduate Education: Accounting as a Case In Point of an Interdisciplinary Dilate. California State University, Los Angeles University Community.

38. Sharma, R., (2000), From Relevance Lost to Relevance Regained: Management Practice in the New Millennium, IFAC.

39. Shilling law, G. (1989), Managerial Cost Accounting: Present and Future. Journal of Management Accounting Research (1), p.33-46.

40. Siegel, G. (2004), Resources Preface, IMA, Institute of Management Accountants.

41. Yau, F.S. \& Minai, B. (1999), Impact of Global Competition on Management Accounting PracticesImplications on Management Accounting Education, Akauntan National April, p.6-12.

42. Zimmerman, J.L. \& Summon, W.E. (2001), Conjectures Regarding Empirical Management Accounting Research Graduate School of Business Administration University of Rochester NY.

\section{FOOTNOTES}

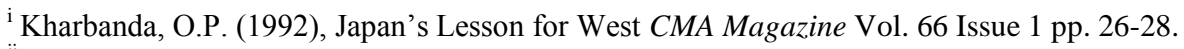

${ }^{i i}$ Chenhall, R.H. \& Langfield-Smith, K., (1998), the Relationship between Strategic Priorities. Management Techniques and Management Accounting: An Empirical Investigation Using a System Approach, Accounting Organization and Society Vol. 23 No. 3 pp. 243-268.

iii Bedford Committee, (1986): Future Accounting Education: Preparing For the Expanding Profession

${ }^{\text {iv }}$ Ibid.

${ }^{v}$ Johnson, H.T. \& Kaplan, R.S., (1987), Relevance Lost: The Rise and Fall of Management Accounting (Boston: Harvard Business School Press).

${ }^{v i}$ Ittner, C.D. \& Larcker, D.F., (2001), Assessing Empirical Research in Management Accounting: A Value- Based Management Perspective. Journal of Accounting and Economics (32): 349-410.

${ }^{\text {vii }}$ Chenhall, R.H. \& Langfield-Smith, K., (1998), the Relationship between Strategic Priorities. Management Techniques and Management Accounting: An Empirical Investigation Using a System Approach, Accounting Organization and Society Vol. 23 No. 3 pp. 243-268.

viii Johnson H.T., (1992), Relevance Regained: From Top Down Control to Bottom Up Empowerment New York Free Press.

${ }^{\text {ix }}$ Sharma, R., (2000), From Relevance Lost to Relevance Regained: Management Practice in the New Millennium, IFAC.

${ }^{x}$ Sharma, R., (2000), From Relevance Lost to Relevance Regained: Management Practice in the New Millennium, IFAC.

${ }^{x i}$ Hawkes, L., Fowler, M.B. \& Tan, L.M. (2004), Management Accounting Curricula: Shaking a Balance between the View of Educators and Praditioners, Accounting Education, (March) Vol. 13, p.3-28.

xii Sharma, R., (2000), From Relevance Lost to Relevance Regained: Management Practice in the New Millennium, IFAC.

xiii Sharma, R., (2000), From Relevance Lost to Relevance Regained: Management Practice in the New Millennium, IFAC.

${ }^{\text {xiv }}$ John Lowry and Christine Yap, Management Accounting: What Skills?, Australian Accountant (1997).

${ }^{x v}$ Forsaith, D., Tilt, C. \& Xydias, M. (n.d.) The Future of Management Accounting: A South Australian Perspective School of Commerce, Flinders University Research Paper Series: 03-2.

${ }^{x v i}$ Hawkes, L., Fowler, M.B. \& Tan, L.M. (2004), Management Accounting Curricula: Shaking a Balance between the View of Educators and Praditioners, Accounting Education, (March) Vol. 13, p.3-28.

${ }^{x v i i}$ Sharma, R., (2000), From Relevance Lost to Relevance Regained: Management Practice in the New Millennium, IFAC.

${ }^{x v i i i}$ Emmanuel, C. Atley, D. \& Merchant, K (.2001), Accounting for Management Control, London, Chapman \& Hall.

${ }^{x i x}$ John Lowry and Christine Yap, Management Accounting: What Skills?, Australian Accountant (1997).

${ }^{\mathrm{xx}}$ Zimmerman, J.L. \& Summon, W.E. (2001), Conjectures Regarding Empirical Management Accounting Research Graduate School of Business Administration University of Rochester NY. 